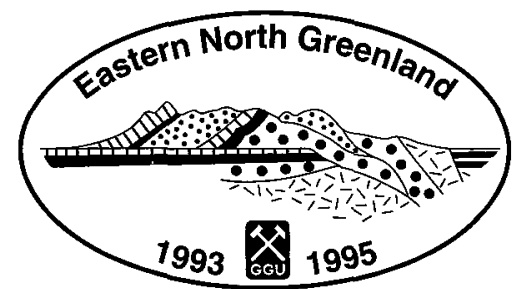

\title{
Eastern North Greenland 1993-1995 \\ - a new 1:500 000 mapping project
}

\author{
Niels Henriksen
}

The Geological Survey of Greenland (GGU) initiated in 1964 a 1:500 000 mapping programme to produce a general overview of the onshore geology of all the ice-free areas of Greenland. So far 10 of a total of 14 planned map sheets have been published, and one additional sheet for which field work has been completed is under compilation. Most of Greenland is therefore now covered by map sheets of this series and only three areas remain to be covered: in North-West Greenland (sheet 6), in eastern North Greenland (sheet 9) and in East Greenland (sheet 11). Eastern North Greenland (map sheet no. 9; Fig. 1) is the target of the present project, with planned field work from 1993-1995. The first season (1993) was used for logistical preparation and geological reconnaissance in advance of the more intensive field work in the two following seasons (1994-95).

The map sheet covers the region between Jökelbugten $\left(78^{\circ} \mathrm{N}\right)$ in North-East Greenland and northern Kronprins Christian Land $\left(81^{\circ} \mathrm{N}\right)$ in eastern North Greenland (Fig. 1). This region lies within the northern part of the East Greenland Caledonian fold belt and is dominated by geological units and problems which have already been encountered during earlier mapping projects to the north (sheets 7 and 8; Henriksen, 1992) and south (sheet 10). Although the geology of the area is complex and variable it has been possible at an early stage to define the work to be carried out and plan the manning and distribution of working areas accordingly. Different geological specialists have been assigned to the mapping projects by combining field teams of the Survey's own staff members with invited external geologists often coming from universities in Denmark and abroad.

All of North and North-East Greenland is covered by a set of wide angle black and white aerial photographs flown in 1978 from an altitude of $14 \mathrm{~km}$. On the basis of these aerial photographs and ground control points established by the Kort- og Matrikelstyrelsen (National Survey and Cadastre - formerly the Geodetic Institute), a new set of topographical maps at a scale of 1:100 000 with $100 \mathrm{~m}$ contours has been drawn at GGU for the entire map sheet area to serve as a basis for the field investigations.

\section{Regional geology studies}

The main regional geological topics to be addressed within the map sheet comprise Caledonian deformation and metamorphism, the sedimentology of late Precambrian and Early Palaeozoic sediments, and the depositional history and structural setting of the post-Caledonian sediments.

The Caledonian studies will focus on the petrology and structure of the crystalline complexes, comprising gneisses and migmatites of probable Lower Proterozoic age which have been subjected to later Caledonian deformation and metamorphism. A detailed structural study of a crosssection through the Caledonian fold belt will attempt to establish the relationships of the infracrustal and supracrustal rock units, which make up a pile of at least three major nappe sheets, and relate the rock sequences to those exposed on the foreland to the west of the fold belt. The structures of Kronprins Christian Land are dominated by thrust tectonics of thin-skinned type in most of the $100 \mathrm{~km}$ wide exposed part of the fold belt.

Late Precambrian sediments of the Hagen Fjord Group occur both as allochthonous elements in the Caledonian fold belt and as largely undeformed successions in the foreland to the west. The partly correlative Rivieradal sandstones are only found in thrust units. These sediments will be studied in order to elucidate their possible relationship with the Eleonore Bay Supergroup basin to the south or the earliest part of the Franklinian Basin to the north.

The Lower Palaeozoic (Ordovician - Silurian) carbonate succession represents the easternmost part of the Franklinian Basin, which extends from northern Canada over most of North Greenland (Higgins et al., 1991). Investigations of the faunal elements in these sediments may lead to correlations with other faunal realms within the North Atlantic region, and thus help to establish the palaeographical relationships between North Greenland and other areas around the proto-Atlantic Ocean (Iapetus Ocean).

The post-Caledonian succession is made up of sediments of Carboniferous to Tertiary age laid down in a series of sedimentary basins collectively referred to as the Wandel Sea Basin (Stemmerik \& Håkansson, 1991; Håkansson et 
$a l ., 1991)$. The studies of the post-Caledonian onshore succession is important due to the widespread distribution of equivalent strata in the areas offshore North-East Greenland revealed by recent seismic surveys (KANUMAS project; Christiansen \& Pulvertaft, 1992).

\section{Economical geological investigations}

GGU's planned activities in eastern North Greenland include special investigations related to the mineral and petroleum potential of the region.

The recent find by the Danish/Greenlandic company Platinova A/S of a large stratiform $\mathrm{Zn}-\mathrm{Pb}$ deposit in Citronen Fjord in northern Peary Land, c. $250 \mathrm{~km}$ north of the map boundary of the present work, has increased expectations for the mineral potential of North Greenland. The Platinova find was primarily based on Survey field observations and geochemical results of the $1978-80$ regional mapping project covering the Peary Land region. The $\mathrm{Zn}-\mathrm{Pb}$ deposits occur in lower Silurian slope and trough deposits of the Franklinian Basin. Results from Platinova's first field investigations show the deposit to be very large, but much more work is required before a reliable estimate of the size and average ore grade can be made (Schønwandt, this report).

A regional geochemical reconnaissance survey based on collection of stream sediments was initiated in 1993. The aim of this work is to obtain a general impression of the element distribution in the region in order to detect possible mineralisation from geochemical anomaly patterns.

Regional hydrocarbon source rock investigations in central and western North Greenland were carried out in connection with previous 1:500 000 mapping programmes, with field work in 1980 and $1984-85$. These have shown that regionally distributed source rocks occur in the Lower Palaeozoic Franklinian Basin at two levels: one of Early to Middle Cambrian age and one of Early Silurian age (Christiansen, 1989).

As the previous petroleum geological investigations were concentrated in central and western North Greenland, there is a need for follow-up work in eastern areas. In eastern North Greenland the hydrocarbon interests also include the Upper Palaeozoic - Tertiary Wandel Sea Basin succession, which has only been provisionally investigated.

\section{Field work in 1993}

The logistical preparations and geological reconnaissance in the summer of 1993 were carried out over approximately one month from the end of June to the beginning of August, with participation of a total of 19 persons, supported by a chartered helicopter and STOL aircraft.
During the 1993 summer a new base camp was established at the west end of Centrum $S \varnothing\left(80^{\circ} 09^{\prime} \mathrm{N}, 22^{\circ} 30^{\prime} \mathrm{W}\right.$; $14 \mathrm{~m}$ a.s.1.). This locality was visited by the US Air Force in 1960 and prepared as an emergency landing strip for large aircraft (N'eedlemann, 1962); the site was also used as a base camp by the Geodetic Institute in 1980, in connection with a regional topographic survey of the Kronprins Christian Land region.

In addition to GGU's geological reconnaissance studies, two glaciological projects were carried out. One study concerned with climatology and the 'greenhouse effect' was based on a special European Community grant, while the second was a cooperative venture with the Alfred Wegener Institut (AWI), Bremerhaven, Germany.

GGU's geological work included studies of: (1) Caledonian crystalline complexes in Lambert Land; (2) Upper Proterozoic - Lower Palaeozoic units in the Caledonian fold belt in southern Kronprins Christian Land; and (3) Upper Palaeozoic Wandel Sea Basin sediments in Holm Land and Amdrup Land on the east coast of Kronprins Christian Land. In addition a systematic collection of stream sediment and water samples was carried out over a large part of the region for a reconnaissance geochemical programme.

The results of the geological reconnaissance investigations are summarised by Jepsen et al. (in press). In Lambert Land the studies took the form of a traverse from Precambrian basement gneisses in the east to younger overlying Middle and Late Proterozoic metasediments in the west. The eastern half of Lambert Land is dominated by basement gneiss units which have suffered intense (?)Caledonian deformation. A prominent $\mathrm{N}-\mathrm{S}$ trending sinistral shear zone, more than $10 \mathrm{~km}$ wide, affects the easternmost part of Lambert Land. This shear zone is probably a northward continuation of the Storstrømmen shear zone found $150 \mathrm{~km}$ to the south (Strachan et al., 1992), and this same shear zone is further traceable for more than $150 \mathrm{~km}$ north of Lambert Land. The gneisses in eastern Lambert Land are structurally overlain by thick sedimentary successions comprising the Middle Proterozoic Independence Fjord Group, and the upper Proterozoic Hagen Fjord Group. The boundary between the gneisses and the supracrustal rocks is a prominent east dipping thrust zone. The intensity of the Caledonian deformation in the supracrustal rocks is variable.

Reconnaissance investigations in Kronprins Christian Land (Jepsen et al., in press) were primarily concerned with stratigraphical and structural problems, building on the results of the earlier preliminary investigations in the area (Fränkl, 1954, 1955; Hurst et al., 1985; Peel, 1985). Units involved in Caledonian thrusts include Lower Proterozoic basement gneisses, metamorphosed middle Proterozoic supracrustal rocks (Independence Fjord Group 


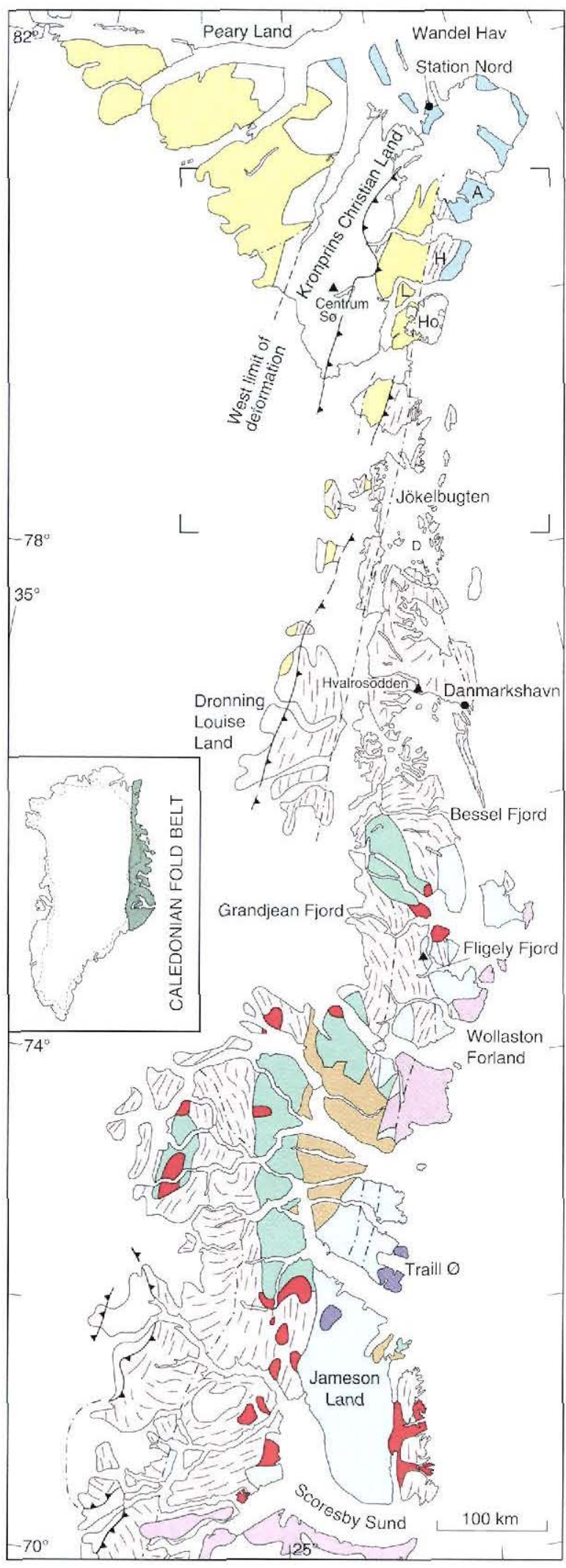

POST - CALEDONIAN

$\square$ Tertiary basalts

$\square$ Tertiary intrusions

Wandel Sea basin: Carboniferous - Tertiary sediments

East Greenland basin: Carboniferous - Cretaceous sediments

LATE TO POST - CALEDONIAN

$\square$ Devonian - continental sediments

\section{CALEDONIAN FOLD BELT}

1 Late to post - kinematic granites

\begin{tabular}{l}
$\square$ \\
$\square$ Late Proterozoic - Ordovician sediments \\
(East Greenland) \\
$\square \quad$ Late Proterozoic - Silurian sediments \\
(North Greenland) \\
$\begin{array}{l}\text { Middle Proterozoic sediments and basalts } \\
\text { (North Greenland) }\end{array}$ \\
\hline,$y$, Crystalline complexes (Archaean - Middle Proterozoic)
\end{tabular}

\section{CALEDONIAN FORELAND}

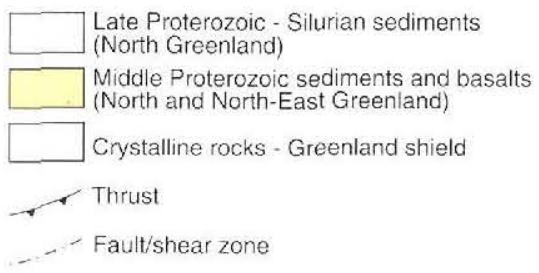

- Base camp

Fig. I. Simplified geological map showing part of the East Greenland Caledonian fold belt, foreland outcrops to the west and northwest and the distribution of post-Caledonian units. A: Amdrup Land: D: Dove Bugt; H: Holm Land: Ho: Hovgaard Ø; L: Lynn $\varnothing$. The frame corners show the extent of the new 1:500 000 map sheet no. 9, Lambert Land. 


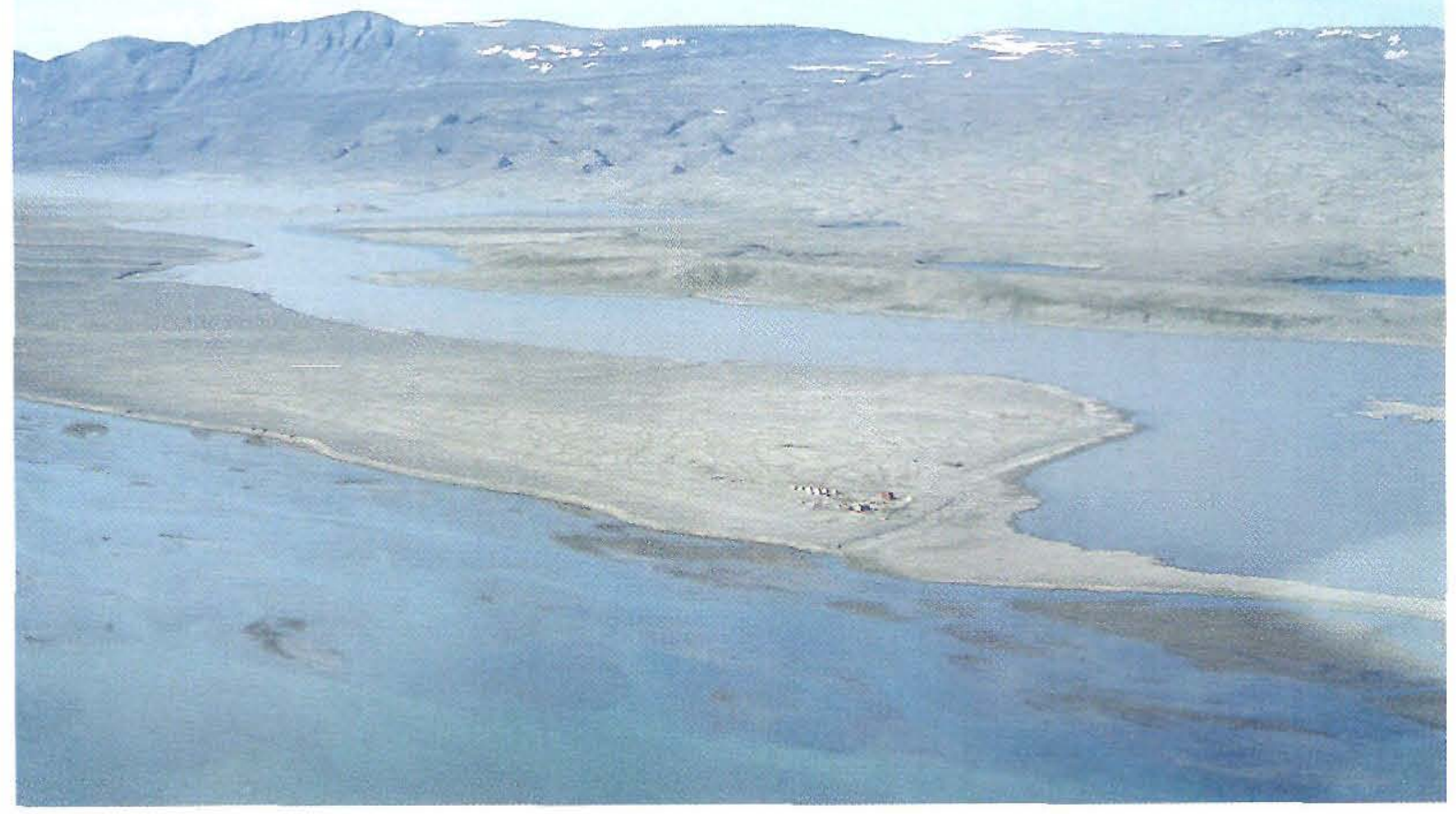

Fig. 2. Base camp site of the North-East Greenland expedition 1993, Centrum So, Kronprins Christian Land.

sandstones and Zig-Zag Dal Basalt Formation) and a succession of Upper Proterozoic and Ordovician - Silurian sediments (Rivieradal sandstones, Hagen Fjord Group sandstones, mudstones and carbonates, Ordovician - Silurian carbonates and Silurian shales). The structures are characterised by thin-skinned tectonic styles with formation of westward displaced nappe complexes. Successions west of the fold belt were briefly visited mainly to check photogeological interpretations.

Work in the Wandel Sea Basin was carried out in Amdrup Land and Holm Land and concentrated on sequence stratigraphic studies in the mid-Carboniferous to Early Permian Mallemuk Mountain Group, which is dominated by shallow water carbonates with minor evaporites and siliciclastics (Stemmerik \& Elvebakk, in press).

During the reconnaissance geochemical programme c. 220 stream sediment and water samples were collected, as well as 17 large sand samples for heavy mineral concentrates. A region of approximately $12000 \mathrm{~km}^{2}$ was sampled, corresponding to a sampling density of one sample per $55 \mathrm{~km}^{2}$. The areas visited included Lambert Land, the western part of Hovgaard $\varnothing$ and Lynn $\varnothing$, the southern part of Kronprins Christian Land and the area around the head of Danmark Fjord. Nearly all the main geological units within the map sheet are represented in the stream sedi- ment sample collection. The samples will be analysed for 45 major and trace elements, and geochemical anomalies suggestive of mineralisation will be followed up by field studies in 1994-95.

During preparation of the 1:100 000 topographic maps in GGU's photogeological laboratory, geological interpretations were made and a set of photogeological maps was drawn using standard GGU procedures (Hougaard et al., 1991). The data have been compiled on a total of 14 photogeological maps at 1:100000, and two 1:250000 map sheets. Significant information arising from the 1993 field work will be added to the maps in preparation for the 1994 season.

\section{Cooperation with other institutions}

GGU's North Greenland project 1993-95 involves extensive scientific and logistic collaboration with other institutions and companies. Two major German geoscientific institutes, the Alfred Wegener Institute for Polar and Marine Research (AWI), Bremerhaven, and the Federal Institute for Geosciences and Natural Resources (BGR), Hannover, both plan field investigations in North Greenland. AWI will continue their glaciological studies of the present dynamic and climatic conditions at the margin of 
the Inland Ice. The work includes surveys along profile lines established in 1989 at Storstrømmen, west of Danmarkshavn $\left(c .77^{\circ} \mathrm{N}\right)$ and at a profile erected in 1993 south-west of Centrum Sø in Kronprins Christian Land (Braithwaite et al., this report). Another AWI activity planned for 1994 is an aeromagnetic survey with fixed wing aircraft working out of Station Nord. The BGR organised project 'Correlations of Alpine Structural Events in Spitsbergen and Greenland; CASE' aims at studying the structure and geotectonic development of the opening of the North Atlantic Ocean between North Greenland and Svalbard, and the field work in North Greenland in 1994 has been planned in co-operation with GGU.

As a result of the discovery of the major stratiform leadzinc deposit at Citronen Fjord by Platinova A/S mentioned above, other companies have also expressed interest in concessions in northern Greenland. This renewed prospecting activity in this remote region has led to planned coordination between the Survey and companies holding concession rights.

In 1993 limited support was given from the Centrum $\mathbf{S} \varnothing$ base camp to a group of biologists and archaeologists working in the Kronprins Christian Land region. This activity was coordinated by the Danish Polar Center (DPC).

\section{References}

Christiansen, F. G. (ed.) 1989: Petroleum geology of North Greenland. Bull. Gronlands geol. Unders. 158, $92 \mathrm{pp}$.

Christiansen, F. G. \& Pulvertaft, T. C. R. 1992: Petroleumgeological activities in 1991: reassessment of areas of earlier exploration, and improvement of information service to industry. Rapp. Gronlands geol. Unders. 155, 28-30.

Fränkl, E. 1954: Vorläufige Mitteilung über die Geologie von Kronprins Christians Land (NE-Grönland). Meddr Gronland $\mathbf{1 1 6}(2), 85 \mathrm{pp}$.

Fränkl, E. 1955: Weitere Beiträge zur Geologie von Kronprins Christians Land (NE-Grönland). Meddr Grønland 103(7) 35 pp.
Håkansson, E., Heinberg, C. \& Stemmerik, L. 1991: Mesozoic and Cenozoic history of the Wandel Sea Basin area, North Greenland. Bull. Gronlands geol. Unders. 160, 153-164.

Henriksen, N. 1992: Geological map of Greenland 1:500 000. Descriptive text. Nyeboe Land, Sheet 7. Peary Land, Sheet 8. 40 pp. Copenhagen: Grønlands Geologiske Undersøgelse.

Higgins A. K., Ineson, J. R., Peel, J. S., Surlyk, F. \& Sønderholm, M. 1991: Lower Palaeozoic Franklinian Basin of North Greenland. Bull. Grønlands geol. Unders. 160, 71-139.

Hougaard, G., Jepsen, H. F. \& Neve, J. K. 1991: GGU's photogeological laboratory: aerial photogrammetry - a valuable geological mapping tool in Greenland. Rapp. Gronlands geol. Unders. 152, 32-35.

Hurst, J. M., Jepsen, H. F., Kalsbeek, F., McKerrow, W. S. \& Peel, J. S. 1985: The geology of the northern extremity of the East Greenland Caledonides. In Gee, D. G. \& Sturt, B. A. (ed.) The Caledonide Orogen - Scandinavia and related areas, 1047 1063. London: John Wiley \& Sons Ltd.

Jepsen, H. F., Escher, J. C., Friderichsen, J. D. \& Higgins, A. K. in press: The northern part of the East Greenland Caledonides $\left(78^{\circ}-81^{\circ} \mathrm{N}\right)-$ photogeological studies and preliminary fieldwork. Rapp. Gronlands geol. Unders.

Needleman, S. M. (ed.) 1962: Arctic earth science investigations, Centrum $S \varnothing$, northeast Greenland, 1960. Air Force surveys in geophysics 138, $132 \mathrm{pp}$.

Peel, J. S. 1985: Cambrian-Silurian platform stratigraphy of eastern North Greenland. In Gee, D. G. \& Sturt, B. A. (ed.) The Caledonide Orogen - Scandinavia and related areas, 10771094. London: John Wiley \& Sons Ltd.

Stemmerik, L. \& Håkansson, E. 1991: Carboniferous and Permian history of the Wandel Sea Basin, North Greenland. Bull. Grønlands geol. Unders. 160, 141-151.

Stemmerik, L. \& Elvebakk, G. in press: A newly discovered midCarboniferous - ?early Permian reef complex in the Wandel Sea Basin, eastern North Greenland. Rapp. Gronlands geol. Unders.

Strachan, R. A., Holdsworth, R. E., Friderichsen, J. D. \& Jepsen, H. F. 1992: Regional Caledonian structure within an oblique convergence zone, Dronning Louise Land, NE Greenland. J. geol. Soc. London 149, 359-371.

\section{N. H., Geological Survey of Greenland, Copenhagen}

